\title{
Spółka cywilna czy jej wspólnicy są podatnikami podatku od nieruchomości?
}

\section{A civil partnership - are its partners the payers of the property tax?}

Streszczenie. Prezentowana publikacja jest próbą uporządkowania istotnego z punktu widzenia prawa podatkowego zakresu praw i obowiązków podatkowych przedsiębiorców podejmujących przedsięwzięcia gospodarcze w ramach umowy spółki cywilnej w obszarze podatku od nieruchomości. Wbrew pozorom ta, niejako prosta forma współpracy gospodarczej, niejednokrotnie stwarza problemy interpretacyjne w obszarze właściwego kwalifikowania podmiotowości podatkowej wspólników, spółki, czy też majątku nabywanego oraz wykorzystywanego we wspólnej działalności gospodarczej. Dlatego też w opracowaniu zaprezentowano ogólne zagadnienia związane z podmiotem i przedmiotem opodatkowania w podatku od nieruchomości, szczegółowo natomiast dokonano analizy statusu prawnego spółki cywilnej i jej wspólników w oparciu o wybrane orzecznictwo, przepisy Kodeksu cywilnego i ustawę o podatkach i opłatach lokalnych. 
Słowa kluczowe: prawo; prawo podatkowe; podatek od nieruchomości; spółka cywilna; przedsiębiorca.

\begin{abstract}
The presented publication is an attempt to order tax obligations and a scope of rights of the entrepreneurs, who are undertaking economic projects under the civil law partnership agreement, which are relevant from the point of view of tax law. Contrary to appearances, this form of economic cooperation, which may seem to be simple one, often times is a source of interpretation problems regarding applicable qualification of the tax subjectivity of the partners, the partnership or the property gained and used in a shared business. Therefore, the paper presents some general issues connected with a subject and an object of taxation in the property tax; however, a detailed analysis of a legal status of the civil partnership and its partners on the basis of the selected case law, the provisions of the Civil Code as well as the act of taxes and local charges, is made.
\end{abstract}

Keywords: law; tax law; property tax; civil partnership; entrepreneur.

\title{
1. Uwagi ogólne
}

Aktualnie podjęcie jakiejkolwiek aktywności gospodarczej przez osoby fizyczne nie jest procesem skomplikowanym i nie wymaga znacznego nakładu czasu. Dzięki czytelnym i prostym zasadom, regulowanym treścią ustawy z dnia 2 lipca 2004 r. o swobodzie działalności gospodarczej ${ }^{1}$, każda osoba fizyczna może w ciągu jednego dnia dokonać rejestracji własnej pozarolniczej działalności gospodarczej i już w tym samym dniu rozpocząć jej wykonywanie.

Istotne dla zamierzonej aktywności gospodarczej jest jednakże nie tylko minimum formalności przewidzianych na start, lecz bez wątpienia sam pomysł co do jej rodzaju, a w szczególności źródła finansowania tej działalności. Nie ulega przecież wątpliwości, iż nawet najlepszy pomysł biznesowy i optymistyczna wizja przyszłości rozpoczynanej pozarolniczej działalności gospodarczej nie wystarczą przecież bez choćby minimalnego wsparcia finansowego, tj. wkładu wnoszonego przez podmiot inicjujący taką działalność.

\footnotetext{
1 Tekst jedn. Dz.U. z 2016 r., poz.1829 ze zm., dalej: u.s.d.g.
} 
O ile podejmowanie jednoosobowej działalności gospodarczej obok spółki z ograniczoną odpowiedzialnością - uznawane jest w Polsce za najbardziej popularną formę prowadzenia działalności, to podjęcie jej w formie umowy cywilnoprawnej, jaką jest umowa spółki cywilnej, również cieszy się dużą popularnością.

Z całą pewnością szybka procedura jej założenia, niemal identyczna jak przy jednoosobowej działalności gospodarczej, w zasadzie mało sformalizowany sposób zawarcia umowy spółki, brak wymogu minimalnego kapitału założycielskiego (wkładu), czy też niskie koszty jej „rejestracji” wpływają na to, iż ta forma prowadzenia działalności zyskała na swojej atrakcyjności.

Jest jeszcze inny, jakże istotny argument, który leży u podstaw popularności tej formy aktywności gospodarczej, a mianowicie wspólne dokapitalizowanie spółki przez jej wspólników wkładami (pieniężnymi, rzeczowymi, know-how), co przy tej formie działalności jest argumentem przeważającym. Również rozłożenie na wszystkich wspólników równej odpowiedzialności, i równego ryzyka podjętych działań nie pozostaje bez znaczenia przed podjęciem decyzji o jej zawiązaniu.

Taką też odpowiedzialnością jest również odpowiedzialność w obszarze zobowiązań publicznoprawnych, m.in. podatku od nieruchomości. W wieloletniej praktyce stosowania przepisów u.p.o.l. pojawiły się jednakże poważne rozbieżności co do podmiotowości podatkowej, gdzie przedmiotem opodatkowania jest nieruchomość, tzn. czy ciężar opodatkowania spoczywa na wspólnikach spółki cywilnej, czy jednak na samej spółce, którą tworzą wspólnicy? Na to kluczowe pytanie w ramach podjętego problemu badawczego, autor zamierza udzielić odpowiedzi w kolejnych rozdziałach opracowania.

\section{Spółka cywilna i jej wspólnicy \\ - status podatkowo-prawny}

Spółka cywilna jest formą prowadzenia działalności gospodarczej, która opiera się na współdziałaniu zdecydowanie osób fizycznych, związanych poprzez zawarcie umowy spółki. Podstawy jej funkcjonowania zostały 
określone w ustawie z dnia 23 kwietnia 1964 r. Kodeks cywilny². Przepisy k.c. stanowią absolutne minimum dla zakresu praw i obowiązków wspólników, co oznacza, że to wspólnicy spółki w treści zawartej umowy mogą szczegółowo doprecyzować zarówno ten zakres, jak i samą treść poszczególnych zapisów łączącej ich umowy. Dotyczy to w szczególności swobody prowadzenia spraw spółki, zasad jej reprezentowania, czy też zasad partycypacji w stratach czy w podziale zysku, jaki osiągnęli wspólnicy w ramach tego przedsięwzięcia gospodarczego.

Pewnym ograniczeniem w zakresie swobody kształtowania postanowień w umowie spółki jest tzw. kontekst ochrony osób trzecich. Dotyczy to odpowiedzialności wspólników spółki cywilnej za zobowiązania wobec osób trzecich, która to odpowiedzialność ma charakter norm ius cogens. Wyraża to treść przepisu art. 864 k.c., zgodnie z brzmieniem którego wspólnicy odpowiadają solidarnie za zobowiązania spółki. Jeżeli zgodnie z treścią umowy niektórzy wspólnicy byliby wyłączeni z odpowiedzialności majątkowej za zobowiązania spółki ${ }^{3}$, to taki zapis umowny ma skutek wyłącznie wewnętrzny, a nie zewnętrzny w relacjach przede wszystkim z wierzycielami.

Co do zasady umowa spółki cywilnej powinna być sporządzona w formie pisemnej. Powstaje pytanie, czy niedochowanie tej formy spowoduje skutek w postaci tzw. utrudnień dowodowych, czy jednak bezwzględną nieważność czynności prawnej. Problematyczne jest to dlatego, iż ustawodawca posługuje się pewnymi zwrotami języka prawnego, które w wielu różnych aktach normatywnych są rozumiane w sposób zgoła odmienny. Takim zwrotem jest słowo „powinna”, „powinien”. Niejednokrotnie słowo to rozumiane jest jako pewna wytyczna czy też zalecenie. Jest ono również traktowane jako pewien nakaz czy też zobowiązanie do określonego zachowania albo określonej formy, np. sporządzenia dokumentu, pisma, dokonania czynności. Zgodnie z internetowym „Słownikiem języka polskiego PWN” słowo „powinien, powinna, powinno”

\footnotetext{
Tekst jedn. Dz.U. z 2017 r., poz. 459, ze zm., dalej: k.c.

Termin „zobowiązania spółki” ma charakter niejako skrótu, bowiem odnosi się w istocie do wspólnego zobowiązania wspólników, pozostającego w związku z działalnością spółki.
} 
oznacza w szczególności, że „coś jest pożądane, konieczne, żeby ktoś coś zrobił,, albo „,jest wskazane, żeby jakaś osoba, rzecz lub jakieś wydarzenie spełniały określone warunki” “ W tym znaczeniu słownikowym słowo to nie nakazuje bezwzględnego sposobu zachowania się, lecz kładzie nacisk na pewien określony, pożądany sposób zachowania się. Stąd też należałoby przyjąć, iż w zawarcie umowy spółki cywilnej bez zachowania formy pisemnej nie przekreśla w żadnej mierze ważności zawartej umowy, jednakże stwarzać może problemy wyłącznie natury dowodowej (art. 860 § 2 w zw. z art. 74 k.c.). Takie samo stanowisko prezentowane jest również w doktrynie ${ }^{5}$.

Spółka cywilna jest umową wspólników, która łączy ich stosunkiem obligacyjnym. Nie jest tym samym podmiotem prawnym odrębnym od jej wspólników, lecz jest wielostronnym stosunkiem zobowiązaniowym łączącym wspólników. W wyniku zawarcia umowy spółki cywilnej nie mamy do czynienia z żadnym innym podmiotem czy jednostką organizacyjną, lecz jedynie ze stosunkiem zobowiązującym wspólników do wspólnego prowadzenia działalności gospodarczej ${ }^{6}$. Jest to ich zobowiązanie do osiągnięcia wspólnego celu gospodarczego (affectio societatis) przez działanie w sposób oznaczony w tej umowie. Działanie to ukierunkowane jest zdecydowanie na osiągnięcie korzyści majątkowych, a za ich podstawę należy uznać cel wspólny wszystkich wspólników.

Kolejną konsekwencją tych założeń jest również wniesienie przez wspólników wkładów. Zastrzec przy tym należy, iż obowiązek ten nie musi obciążać wszystkich wspólników, bowiem niektórzy zamiast wkładu mogą zobowiązać się do innych określonych w umowie świadczeń, co potwierdza treść przepisu art. $861 \S 1$ k.c.

Spółkę cywilną mogą tworzyć jako jej uczestnicy zarówno osoby fizyczne, jak i osoby prawne, a minimalna liczba tych wspólników to skład co najmniej dwuosobowy. Przystąpienie do spółki osoby prawnej nie

\footnotetext{
Słownik języka polskiego PWN, www.sjp.pwn.pl (dostęp: 22.03.2017 r.).

Z. Radwański, J. Panowicz-Lipska, Zobowiq̨zania - część szczegółowa, Warszawa 2015, s. 327.

6 G. Dudar, Wspólnicy spółki cywilnej jako podatnicy podatku od nieruchomości, „Przegląd Podatków Lokalnych i Finansów Samorządowych” 2015, nr 4, s. 32.
} 
zmienia jednakże w żadnym stopniu charakteru prawnego tego stosunku zobowiązaniowego. Spółka cywilna, niezależnie od statusu prawnego jej uczestników, nie ma ani osobowości prawnej, ani zdolności prawnej, a w rezultacie nie przysługuje jej także atrybut zdolności do czynności prawnych $^{7}$. Konsekwencją takiego stanu jest to, że nie jest ona osobnym podmiotem prawa $^{8}$ cywilnego, czyli nie może samodzielnie występować w obrocie prawnym jako jego odrębny podmiot.

Dlatego też dla potrzeb m.in. prawa podatkowego nie może być zdecydowanie uznaną za przedsiębiorcę w rozumieniu u.s.d.g.

Przywołać należy w tym miejscu postanowienia art. 4 ust. 2 u.s.d.g., w którym to przepisie ustawodawca przesądził, że przedsiębiorcami są poszczególni wspólnicy spółki cywilnej w zakresie wykonywanej przez nich działalności gospodarczej. Zgodne jest to z wyrażanym już wcześniej poglądem prezentowanym w orzecznictwie Sądu Najwyższego, który to odmawiał spółce cywilnej statusu przedsiębiorcy ${ }^{9}$.

W imieniu spółki działalność gospodarczą wykonują tym samym jej wspólnicy jako zarejestrowani w rejestrze przedsiębiorców (Centralnej Ewidencji i Informacji o Działalności Gospodarczej, Krajowym Rejestrze Sądowym) przedsiębiorcy. Znaczenie takiego ukształtowania podmiotowości w ramach spółki cywilnej przejawia się m.in. tym, że opodatkowania dochodu w rozumieniu ustawy o podatku dochodowym uzyskiwanego w ramach prowadzonej spółki dokonują jej wspólnicy, a nie spółka.

Ten stan rzeczy ma także bardzo ważne znaczenie dla przedsiębiorców, którzy wspólny cel gospodarczy osiągają w ramach łączących ich umów spółek cywilnych, w obszarze obowiązków podatkowych, w odniesieniu do podatków stanowiących dochody budżetów gmin, w tym przede wszystkim podatku od nieruchomości.

7 Uchwała składu 7 sędziów Sądu Najwyższego z dnia 31 marca 1993 r., III CZP 176/92, „Orzecznictwo Sądu Najwyższego - Izba Cywilna/Pracy” 1993, nr 10, poz. 171.

8 J. Lic, Skutki braku podmiotowości spótki cywilnej prowadzqcej działalność gospodarczq, „Przegląd Prawa Handlowego”, 2006, nr 1, s. 47.

9 Uchwała składu 7 sędziów Sądu Najwyższego z dnia 26 stycznia 1996 r., III CZP 111/95, „Orzecznictwo Sądu Najwyższego - Izba Cywilna/Pracy” 1996, nr 5, poz. 63. 


\section{Spółka cywilna a podatek od nieruchomości}

Podatek od nieruchomości jest podatkiem, który zasila dochody gmin i dzięki któremu gminy uzyskują największe wpływy podatkowe. Przy czym największe wpływy generują wielkie metropolie, co jest oczywiste z uwagi na ich obszar, urbanizację, infrastrukturę, a także dużą liczbę podmiotów prowadzących pozarolniczą działalność gospodarczą, co ma znaczenie dla wyższego poziomu opodatkowania przedmiotów zajętych na jej prowadzenie ${ }^{10}$.

Podatek od nieruchomości jest obecny w polskim systemie podatkowym od początku $1991 \mathrm{r}$. uregulowany ustawą z dnia 19 stycznia $1991 \mathrm{r}$. o podatkach i opłatach lokalnych ${ }^{11}$.

Przedmiot opodatkowania tym podatkiem jest określony treścią art. 2 u.p.o.l., który ma charakter prawny numerus clausus, co oznacza, że wyliczenie to jest katalogiem zamkniętym. Ta zamknięta lista elementów wskazuje wszystkie dopuszczalne przedmioty opodatkowania i poza którą to nie można wychodzić. Zgodnie $\mathrm{z}$ aktualnie obowiązującym stanem prawnym opodatkowaniu podatkiem od nieruchomości podlegają nieruchomości lub obiekty budowlane, do których ustawodawca zaliczył:

- grunty,

- $\quad$ użytki rolne, grunty zadrzewione i zakrzewione na użytkach rolnych lub lasy, zajęte na prowadzenie działalności gospodarczej, - budynki lub ich części,

- budowle lub ich części związane z prowadzeniem działalności gospodarczej.

Formułując pozytywny katalog przedmiotów opodatkowania, prawodawca konstruuje w istocie dwa kryteria - lub grupy kryteriów - jego wyodrębnienia. Po pierwsze przedmiotem opodatkowania są „nieruchomości i obiekty budowlane”. Drugim kryterium jest to, aby owe nieruchomości lub obiekty budowlane zaliczały się do kategorii gruntów, bu-

10 M. Macudziński, Czy hale namiotowe podlegaja podatkowi od nieruchomości?, „Prawo Budżetowe Państwa i Samorządu” 2016, nr 4, s. 10, DOI: http://dx.doi.org/10.12775/PBPS.2016.020.

11 Tekst jedn. Dz.U. z 2017 r., poz. 1785., dalej: u.p.o.l. 
dynków lub ich części albo budowli lub ich części, z tym że budowle muszą być związane z prowadzeniem działalności gospodarczej ${ }^{12}$.

Odpowiednie zakwalifikowanie posiadanych rzeczy do właściwych kategorii nieruchomości, w zasadzie nie powinno być kłopotliwe, tym niemniej najwięcej problemów w zakresie prawidłowego stosowania u.p.o.l. dotyczy przede wszystkim opodatkowania budowli. W tym też zakresie pojawia się jednakże wiele wątpliwości i kłopotów interpretacyjnych, m.in. w prawidłowym ustalaniu ich wartości. Stąd też pojawiły się postulaty, iż należałoby albo zlikwidować pojęcie budowli, albo nazwać nią ściśle określone obiekty ujęte w klasyfikacji środków trwałych. Pomysłem godnym rozważenia mogłoby być ujęcie ich w specjalnym załączniku do ustawy. To samo można zrobić również z budynkami ${ }^{13}$.

Podatnikami podatku od nieruchomości zgodnie z art. 3 ust. 1 u.p.o.l. są natomiast osoby fizyczne oraz prawne, jednostki organizacyjne, w tym spółki nieposiadające osobowości prawnej, będące:

- właścicielami i posiadaczami samoistnymi nieruchomości lub obiektów budowlanych,

- użytkownikami wieczystymi gruntów,

- posiadaczami nieruchomości lub ich części albo obiektów budowlanych lub ich części, stanowiących własność Skarbu Państwa lub jednostki samorządu terytorialnego, jeżeli posiadanie wynika z umowy zawartej z właścicielem, Agencją Nieruchomości Rolnych lub z innego tytułu prawnego, z wyjątkiem posiadania przez osoby fizyczne lokali mieszkalnych niestanowiących odrębnych nieruchomości, a także wówczas, gdy posiadanie to jest bez tytułu prawnego.

Powyższe skłania do postawienia kluczowego pytania, czy z treści powołanych wyżej regulacji prawnych możliwe jest jednoznaczne ustale-

12 T. Brzezicki, K. Lasiński-Sulecki, W. Morawski, P. Majka, Ustawa o podatkach i opłatach lokalnych. Komentarz, Gdańsk 2016, s. 184.

13 Orędownikiem takiego pomysłu jest m.in. prof. dr hab. L. Etel. Zob. wywiad udzielony „Rzeczpospolitej” z dnia 4 czerwca 2012 r.; http://www.rp.pl/artykul/886508Leonard-Etel--podatek-od-nieruchomosci-do-zmiany.html\#ap-1, (dostęp: 25.05.2017 r.). 
nie, kto w obszarze podatku od nieruchomości jest jego podmiotem, tj. czy jest nim spółka cywilna, czy jednak wyłącznie jej wspólnicy?

Punktem wyjścia do znalezienia odpowiedzi na tak postawione pytanie jest odniesienie się do wcześniejszych, wstępnych rozważań dotyczących statusu wspólnika jako przedsiębiorcy w stosunku zobowiązaniowym, jakim jest umowa spółki cywilnej. Wskazano, w oparciu o przytoczone regulacje prawne, iż to wspólnik spółki jako przedsiębiorca jest podmiotem prawa podatkowego, a nie sama spółka.

Wskazuję jednakże, iż w zakresie prawidłowego kwalifikowania przedmiotu opodatkowania, jaką jest szeroko rozumiana nieruchomość (w tym też budowla), którą wykorzystują wspólnicy spółki cywilnej dla potrzeb prowadzonej przez nich działalności gospodarczej, pojawiały się poważne rozbieżności.

Pomińmy przy tym już sam szczegółowy sposób wprowadzenia nieruchomości do stosunku zobowiązaniowego, jakim jest umowa spółki, rozważmy natomiast, kto faktycznie posiada ogół praw i obowiązków związanych z taką nieruchomością, wspólnicy spółki cywilnej czy jednak spółka, którą ci wspólnicy współtworzą?

Bez wątpienia nieruchomości wykorzystywane przez wspólników spółki cywilnej, których celem jest określony cel gospodarczy, traktować należy jako nieruchomości zajęte na prowadzenie działalności gospodarczej lub związane z prowadzeniem takiej działalności. Czy w takim razie należałoby wprost uznać, iż taka nieruchomość jest własnością spółki cywilnej, którą to wspólnicy wykorzystują tylko do działalności gospodarczej?

Kluczowe dla tej kwestii jest wskazanie, że w związku z brakiem podmiotowości prawnej spółki cywilnej skutkuje to tym, że taka spółka nie ma jednakże żadnego własnego majątku. Nieruchomość wniesiona jako wkład przez wspólników czy nabyta dopiero w czasie trwania spółki stanowi wspólny majątek wszystkich wspólników i stanowi współwłasność łączną, tzw. wspólność niepodzielnej ręki, co potwierdza normatyw przepisu art. 863 k.c.

Dlatego też należy uznać, iż właścicielami nieruchomości w spółce cywilnej są jej wspólnicy, a nie spółka. Nie ma ona bowiem podmiotowo- 
ści prawnej na gruncie prawa cywilnego i nie może tym samym być właścicielem żadnej nieruchomości. Powyższe pozwala na przyjęcie logicznego wniosku, iż decyzja organu podatkowego ustalająca zobowiązanie w podatku od nieruchomości powinna być skierowana do właściwych jej adresatów, tj. wspólników spółki cywilnej, a nie do samej spółki.

W obszarze stosowania prawa podatkowego, a w szczególności u.p.o.l pojawiły się jednakże wątpliwości, czy faktycznie to wspólnicy, a nie spółka powinni być adresatami takich decyzji. Z pewnością takie wątpliwości znajdują swoje źródło w treści przepisu art. 3 ust. 1 u.p.o.l., zgodnie z którym poza osobami fizycznymi i prawnymi również takie podmioty jak jednostki organizacyjne nieposiadające osobowości prawnej są podatnikami podatku od nieruchomości, o ile oczywiście zaistnieją stany faktyczne uzasadniające powstanie obowiązku podatkowego w tym podatku.

Czy zatem słuszne jest traktowanie spółki cywilnej jako jednostki organizacyjnej nieposiadającej osobowości prawnej, skoro nie jest ona ani osobą fizyczną, ani osobą prawną?

Moim zdaniem odpowiedź przeczącą na tak postawione pytanie znajdujemy w k.c., a mianowicie w jego art. 33¹, który stanowi jedną z podstaw dla słuszności takiego stanowiska. Z postanowień k.c. dotyczących umowy spółki nie wynika przecież, iż spółka cywilna została zaopatrzona w jakąkolwiek podmiotowość prawną, posiadającą prawa i obowiązki. Spółka cywilna nie posiada również zdolności prawnej, jest wyłącznie formalnym i wspólnym zobowiązaniem wspólników. Nie może tym samym nabywać prawa i zaciągać zobowiązania mocą swojego działania, nie może także pozywać i być pozywaną. Dlatego też błędem jest włączanie do katalogu jednostek organizacyjnych nieposiadających osobowości prawnej spółki cywilnej (która jest przecież umownym stosunkiem zobowiązaniowym), a tym samym obciążać ją, a nie jej wspólników podatkiem od nieruchomości.

W literaturze przedmiotu słusznie zwraca się uwagę, że podatnikiem może być tylko taki podmiot, który ma możliwość znalezienia się w za- 
kresie przedmiotowym podatku ${ }^{14}$. Uczynienie natomiast podatnika podatku od własności nieruchomości podmiotu, który właścicielem być nie może (np. spółki cywilnej), byłoby rozwiązaniem trudnym do zaakceptowania $^{15}$.

Wyeksponowanie powyższego stanowiska jest o tyle istotne w aktualnym stanie prawnym, że problem podmiotowości prawnopodatkowej spółki cywilnej pojawiał się wielokrotnie, m.in. w niektórych orzeczeniach sądów administracyjnych, a w nich i stanowiska, uznające za podatnika podatku od nieruchomości właśnie spółkę cywilną, a nie jej poszczególnych wspólników.

Za takim kwalifikowaniem podmiotowości prawnej spółki cywilnej opowiadał się, np. Naczelny Sąd Administracyjny, który w jednym z wyroków ${ }^{16}$ wskazał, że spółka cywilna, chociaż nie posiada osobowości prawnej, jest powszechnie uznawana za korporację, to jest zrzeszenie osób mające na celu realizację określonych wspólnych zadań, stanowi określoną organizację, a więc jest zindywidualizowaną i konkretną jednostką organizacyjną. W ramach spółki cywilnej może funkcjonować przedsiębiorstwo w rozumieniu kodeksu cywilnego, prowadzone w celach zarobkowych. Z przedstawionych w orzeczeniu unormowań oraz ich w ocenie sądu - prawidłowej wykładni sformułowano konkluzję, w której NSA zdecydowanie uznał, że na podstawie art. 3 ust. 1 pkt 4 lit. a u.p.o.l. podatnikiem podatku od nieruchomości jest spółka cywilna, a nie jej wspólnicy.

Powołane stanowisko z całą pewnością jest również konsekwencją m.in. wcześniejszego orzeczenia NSA z 31 marca 2004 r. ${ }^{17}$, w którym stwierdzono, iż stosownie do art. 3 ust. 1 u.p.o.l. to spółce cywilnej jako organizacji wspólników, a nie wspólnikom, przekazano podmiotowość prawnopodatkową, co w konsekwencji pozwala na uznanie spółki cywil-

14 Szerzej na temat podmiotowości podatkowej: M. Kalinowski, Podmiotowość prawna podatnika, Toruń 1999.

15 T. Brzezicki, K. Lasiński-Sulecki, W. Morawski, J. Wantoch-Rekowski, Ustawa o podatkach i opłatach lokalnych. Komentarz, Gdańsk 2009, s. 332.

16 Wyrok NSA z dnia 25 kwietnia 2008 r., II FSK 227/07, Centralna Baza Orzeczeń Sądów Administracyjnych (CBOSA).

17 FSK 567/04, CBOSA. 
nej podatnikiem podatku od nieruchomości. W takim razie, jak stwierdził sąd, decyzja określająca podatek od nieruchomości winna być skierowana do spółki cywilnej ${ }^{18}$.

Innym przykładem wpisującym się w tą niewłaściwą w mojej ocenie wykładnię przepisów prawa podatkowego jest pogląd wyrażony w artykule opublikowanym w jednej z bardzo poczytnych specjalistycznych gazet podatkowych $^{19}$, w którym udzielono odpowiedzi na pytanie zadane przez czytelników. Wspólnicy spółki cywilnej nabyli nieruchomość gruntową zabudowaną budynkiem z zamiarem wykorzystywania jej na potrzeby prowadzonej działalności gospodarczej i w związku z tym mieli wątpliwość, kto w tym przypadku będzie opłacać podatek od nieruchomości: spółka czy poszczególni wspólnicy? Udzielając odpowiedzi na tak postawione pytanie, jednoznacznie opowiedziano się za tym, iż spółka nieposiadająca osobowości prawnej, a taką jest spółka cywilna, będzie podatnikiem podatku od nieruchomości. Przywołano przy tym również orzeczenie Wojewódzkiego Sądu Administracyjnego w Gliwicach ${ }^{20}$, który stwierdził, iż w sytuacji, gdy nieruchomość została nabyta przez wspólników spółki cywilnej dla celów prowadzenia działalności gospodarczej, podatnikiem podatku od nieruchomości będzie spółka jako jednostka organizacyjna nieposiadająca osobowości prawnej. W konkluzji przyjęto wniosek, iż spółki niemające osobowości prawnej zobowiązane są składać, w terminie do 31 stycznia, organowi podatkowemu właściwemu ze względu na miejsce położenia przedmiotów opodatkowania, deklaracje na podatek od nieruchomości na dany rok podatkowy, sporządzone na formularzu według ustalonego wzoru.

Powołane wyżej sposoby interpretacji przepisów prawa podatkowego nie przystają jednakże do zaprezentowanego wyżej statusu przedsiębior-

18 Podobny kierunek interpretacyjny, i poglądy na temat podmiotowości spółki cywilnej zostały zaprezentowane w innych orzeczeniach sądów administracyjnych, m.in w wyroku NSA z dnia 14 lutego 2003 r., I SA/Gd 645/00, LEX 299467, wyroku WSA w Gliwicach z dnia 31 stycznia 2008 r., I SA/Gl 167/07, CBOSA, wyroku NSA z dnia 25 kwietnia 2008 r., II FSK 229/07, CBOSA.

19 K. Romas, Spółka cywilna podatnikiem podatku od nieruchomości, „Gazeta Podatkowa” 2013, nr 79 (1016), s. 18.

20 Wyrok z dnia 15 kwietnia 2013 r., I SA/Gl 207/13, CBOSA. 
ców, realizujących wspólny cel gospodarczy w ramach stosunku zobowiązaniowego, jakim jest po prostu umowa spółki. Ten istotny dla przedmiotu opodatkowania status podmiotów tworzących spółkę cywilną w ogóle nie został dostrzeżony, a tym samym oceniony przez składy orzekające, co mogło mieć wpływ na podjęcie zaprezentowanych, błędnych niestety, rozstrzygnięć orzekających.

Przyznać jednakże należy, iż to sam ustawodawca nie ułatwił zadania podmiotom stosującym prawo, wkomponowując w ich treść taki podmiot, jak ,jednostka organizacyjna nieposiadająca osobowości prawnej”, bez niezbędnego, ustawowego jej zdefiniowania. Ten stan rzeczy niewątpliwie również wpłynął na rozbieżności we właściwym rozumieniu „podmiotowości” spółki cywilnej w obrocie gospodarczym, których wyraz dały m.in. treści powołanych orzeczeń sądów administracyjnych.

Wskazanym wyżej, w mojej ocenie błędnym stanowiskom, przeciwstawić należy zdecydowanie inny pogląd na podmiotowość wspólników spółki cywilnej i samej spółki cywilnej, który jest aktualnie jedyny do zaakceptowania i zgodny z ratio legis u.p.o.l. i przepisów prawa cywilnego.

Wystarczy przywołać na wstępie stanowisko wybitnych znawców problematyki prawa podatkowego, a w szczególności podatków i opłat lokalnych, m.in. prof. dr hab. L. Etela, który w komentarzu do art. 3 u.p.o.l. ${ }^{21}$ wykazał, że jedynie wspólnicy spółki cywilnej, a nie spółka, mogą być właścicielami, użytkownikami wieczystymi lub posiadaczami nieruchomości, a zatem tylko oni mogą być podatnikami podatku od nieruchomości.

Prezentowany pogląd jest również w pełni akceptowany przez prof. dr hab. Wojciecha Morawskiego, który wespół z innymi przedstawicielami doktryny przedstawił go m.in. w komentarzu do podatku od nieruchomości, w którym zdecydowanie odrzucono możliwość zaliczenia spółki cywilnej do jednostek organizacyjnych nieposiadających osobowości prawnej, a tym samym uznaniu jej za podatnika podatku od nieruchomości.

21 L. Etel, Ustawa o podatkach i opłatach lokalnych. Komentarz, Warszawa 2009, System Informacji Prawnej Legalis, (dostęp: 26.03.2017 r.); L. Etel, S. Presnarowicz, G. Dudar, Podatki i opłaty lokalne, podatek rolny, podatek leśny, Komentarz, Warszawa 2008, s. 122. 
Spółka cywilna nie może tym samym być właścicielem, użytkownikiem wieczystym czy posiadaczem budynków, budowli lub gruntów. W konsekwencji wykazano, że sądy błędnie dopuszczają możliwość opodatkowania spółki cywilnej w oderwaniu od przedmiotu opodatkowania. Koncentrują się tylko na organizacyjnym aspekcie spółki cywilnej (co jest argumentem wątpliwym ze względu na zobowiązaniowy charakter nawiązanego stosunku prawnego w zakresie spółki cywilnej), nie zaś na przedmiocie opodatkowania (spółka nigdy nie spełni warunków umożliwiających jej opodatkowanie - nie będzie właścicielem czy posiadaczem przedmiotu opodatkowania). Stanowisko uznające spółkę cywilną za podatnika podatku od nieruchomości należy uznać za niedopuszczalne i nieznajdujące racjonalnego uzasadnienia $\mathrm{w}$ świetle obowiązujących przepisów ${ }^{22}$.

Komentatorzy u.p.o.l. zdecydowanie podnoszą, iż uznanie za podatnika spółki cywilnej, która uiścić podatku nie może, powodowałoby chyba, że podatnikami nie mogliby być już jej wspólnicy. Ten wniosek jest dość dyskusyjny, gdyż to wspólnicy są właścicielami przedmiotu opodatkowania. Jednak skoro sądy „przypisują” przedmiot opodatkowania do majątku spółki, to jak pogodzić to z jednoczesnym „przypisywaniem” go do majątku wspólników? Jak widać „upodmiotowienie” na gruncie podatku od nieruchomości spółki cywilnej prowadzi do absurdalnych wniosków ${ }^{23}$.

Za przedstawionymi poglądami przemawiają także zbieżne poglądy występujące w literaturze przedmiotu wskazujące na to, iż jeżeli spółka cywilna nie jest i nie może być właścicielem nieruchomości, to w konsekwencji nie może być podatnikiem ${ }^{24}$ podatku, którego przedmiotem jest nieruchomość.

22 T. Brzezicki, K. Lasiński-Sulecki, O. Łunarski, P. Majka, W. Morawski, J. Wantoch-Rekowski, Podatek od nieruchomości w orzecznictwie sqdów administracyjnych. Komentarz. Linie interpretacyjne, Wolters Kluwer, Warszawa 2013, s. 369-370.

T. Brzezicki, K. Lasiński-Sulecki, W. Morawski, P. Majka, Ustawa..., s. 216.

24

G. Dudar, Spółka cywilna w podatku od nieruchomości, Przegląd Podatków Lokalnych i Finansów Samorządowych, 2008 nr 7-8, s. 15; G. Dudar, Glosa do wyroku WSA w Krakowie z 3 marca 2009 r., sygn. akt: I SA/Kr 1601/08, „Finanse Komunalne” 2010, nr 4, s, 73; K. Heliniak, P. Majka, Glosa do wyroku Naczelnego Sqdu Admini- 
Potwierdzeniem i słusznym rozumieniem omawianej problematyki jest również część poglądów prezentowanych w orzecznictwie sądowoadministracyjnym, co przyjąć należy z zadowoleniem. Wskażę, m.in. na postanowienie $\mathrm{NSA}^{25}$, w którym co prawda mylnie uznano, iż spółka cywilna jest jednostką organizacyjną nieposiadającą osobowości prawnej, to jednak wskazano, że nie może jej przysługiwać żaden z wymienionych w u.p.o.l. tytułów do władania nieruchomością. Przede wszystkim spółka cywilna nie może być właścicielem nieruchomości, gdyż wniesiona do spółki nieruchomość staje się wspólnym majątkiem jej wspólników. Jest to specyficzna forma wspólności łącznej przysługująca wszystkim wspólnikom. To pozwoliło sądowi dojść do wniosku, że skoro spółka cywilna nie może być właścicielem nieruchomości, tym samym nie może być podatnikiem podatku od nieruchomości. Obowiązek podatkowy ciąży bowiem wyłącznie na właścicielu bądź współwłaścicielach nieruchomości.

Nadmienię nadto, iż upatrywanie w spółce cywilnej tylko stosunku zobowiązaniowego zamiast korporacyjnego charakteru pojawiało się również w niektórych orzeczeniach wojewódzkich sądów administracyjnych, w których to wyrażano stanowisko zgodne, $\mathrm{z}$ od lat prezentowanymi poglądami doktryny, że to wspólnicy, a nie spółka cywilna powinni być opodatkowani podatkiem od nieruchomości ${ }^{26}$.

Z satysfakcją należy przyjąć również, iż pogląd o niepodleganiu przez spółkę cywilną opodatkowaniu podatkiem od nieruchomości oraz o objęciu zakresem podmiotowym podatku od nieruchomości wyłącznie wspólników tych spółek, a więc tożsamy z tym, za którym opowiadają się przedstawiciele doktryny, prezentowany jest również w innych aktualnych orzeczeniach wojewódzkich sądów administracyjnych i orzeczeniach

stracyjnego z dnia 31 marca 2005 r., (FSK 567/04), „Przegląd Orzecznictwa Podatkowego" 2007, nr 3, s. 212-217.

25 Postanowienie NSA z dnia 16 grudnia 2014 r., II FSK 2985/12, CBOSA.

26 Na przykład wyrok WSA w Poznaniu z dnia 21 kwietnia 2006 r., I SA/Po 403/05, CBOSA; wyrok WSA w Poznaniu z dnia 23 maja 2007 r., I Sa/Po 172/07, CBOSA; wyroki WSA w Poznaniu z dnia 16 kwietnia 2008 r.: I SA/Po 109/08 oraz SA/Po 116/08, CBOSA. 
$\mathrm{NSA}^{27}$. Mieć należy przy tym nadzieję, iż w prezentowanym zakresie zarówno przedmiotowym, jak i podmiotowym u.p.o.l. dojdzie w końcu do ujednolicenia poglądów sądownictwa z głoszonymi od dawna w tym zakresie poglądami przedstawicieli nauki.

Kluczowe dla podjętego problemu badawczego jest niewątpliwie stanowisko samego Ministra Rozwoju i Finansów, który do problematycznego zagadnienia podmiotowości w spółkach cywilnych odniósł się w sposób formalny, a mianowicie wydając interpretację ogólną w sprawie opodatkowania podatkiem od nieruchomości wspólników spółek cywilnych ${ }^{28}$. Organ interpretujący stwierdził, że w przypadku spółki cywilnej podatnikami podatku od nieruchomości są jej wspólnicy, a sama spółka cywilna stanowi jedynie stosunek zobowiązaniowy wspólników (a tym samym nie może ona nabyć we własnym imieniu praw). Jak wskazał organ podatkowy, spółka cywilna nie jest podatnikiem podatku od nieruchomości, gdyż nie może we własnym imieniu nabywać praw, w tym własności nieruchomości, nie może stać się posiadaczem samoistnym nieruchomości, użytkownikiem wieczystym gruntu ani posiadaczem mienia jednostek samorządu terytorialnego lub Skarbu Państwa.

Dlatego też, biorąc pod uwagę duże rozbieżności pojawiające się przy wykładni u.p.o.l., powołana interpretacja ogólna jest bez wątpienia bardzo cennym instrumentem, który powinien przyczynić się do ujednolicenia rozstrzygnięć w zakresie podatku od nieruchomości, dokonywanych przez samorządowe organy podatkowe wobec uczestników spółek cywilnych.

Pozwolę sobie w tym miejscu na refleksję, jaka aktywuje się w związku z wydaną interpretacją organu podatkowego, a sprowadzająca się do tego, że owa interpretacja nie jest niczym nowym, a zarazem twórczym w ramach podjętego i przedstawianego problemu badawczego. Stanowi ona wyłącznie potwierdzenie stanowisk, co do podmiotowości wspólników spółki cywilnej, które przez wiele lat były niezmiennie pre-

27 Zob. np. wyrok WSA w Poznaniu z dnia 19 listopada 2013 r., III SA/Po 613/13, CBOSA, wyrok NSA z dnia 29 stycznia 2016 r., II FSK 3264/13, CBOSA, wyrok NSA z dnia 3 lutego 2016 r., II FSK 2368/14, CBOSA.

28 Interpretacja Ogólna Ministra Rozwoju i Finansów Nr PS2.8401.2.2016 z dnia 21 października 2016 r. (Dz.Urz. Ministra Rozwoju i Finansów z 2016 r., poz. 10). 
zentowane przez wybitnych przedstawicieli nauki prawa podatkowego, w przeciwieństwie do różnych skrajnych i zmiennych poglądów sądownictwa administracyjnego. O ile, będąc świadomym, jak ważna jest urzędowa interpretacja przepisów prawa podatkowego przy jego stosowaniu, to również uznać z powagą należy, iż w przedstawionym świetle jest ona z całą pewnością pewnym ukłonem w stronę specjalistów prawa podatkowego, których głos zdecydowanie częściej należałoby uwzględniać przy tworzeniu, stosowaniu i interpretowaniu skomplikowanych przepisów prawa podatkowego.

Na poparcie słuszności poglądu, iż wykładnia u.p.o.l. niejednokrotnie prowadziła do wielu rozbieżnych stanowisk, co jest uciążliwe i zarazem trudne do zaakceptowania przez doktrynę ${ }^{29}$, a tym bardziej przez samych podatników, jest przedstawienie przez NSA omawianego problemu do rozstrzygnięcia rozszerzonemu składowi siedmiu sędziów, w związku z rozpatrywaniem skargi kasacyjnej w sprawie oznaczonej sygnaturą akt II FSK 1962/16.

Rozstrzygnięcie zagadnienia prawnego zapadło 13 marca 2017 r., kiedy siedmioosobowy skład NSA podjął uchwałę ${ }^{30}$, w której wskazał, iż w rozumieniu art. 3 ust. 1 u.p.o.l. podatnikiem podatku od nieruchomości są wspólnicy spółki cywilnej, a nie sama spółka cywilna. Zatem wszelkie decyzje podatkowe winny być kierowane do jedynych jej adresatów, tj. wyłącznie do wspólników spółki, którzy solidarnie odpowiadają za zapłatę tego podatku.

Niniejsza konkluzja w całości wkomponowuje się w prezentowane zarówno stanowisko przedstawicieli doktryny, autora, jak i w konsekwen-

29 Na funkcjonującą od 25 lat u.p.o.l. spada krytyka ze wszystkich stron, m.in. prywatnych właścicieli, przedsiębiorców, gmin, samorządowych kolegiów odwoławczych oraz sądów, co wyraźnie zaakcentowali uczestnicy debaty zorganizowanej przez „Dziennik Gazetę Prawną”, której treść opublikowano w artykule „Przepisy o podatkach lokalnych”, DGP z dnia 8 maja 2017 r., s. B4 (1-2). Dobitnie istniejący stan prawny i faktyczny u.p.o.l. wyeksponował Wojciech Morawski, który stwierdził m.in., iż: „Dla osoby niezorientowanej, nieznajq̨cej orzecznictwa, które w określony sposób ukształtowało rozumienie podstawowych zagadnien, podatek od nieruchomości jest kompletnie niezrozumiały. [...] Prawdę mówiq̨c, my nie mamy już ustawy o podatkach i opłatach lokalnych".

30 Sygn. II FPS 5/16, CBOSA. 
cji wyeksponowane wyżej stanowisko Ministra Rozwoju i Finansów co do podmiotowości podatkowej wspólników spółki cywilnej w obszarze podatku od nieruchomości.

Dlatego z pełną odpowiedzialnością i przekonaniem, mając na uwadze świadomość właściwego rozumienia zakresu normowania u.p.o.l., ad extrmum wypada wyeksponować jeszcze raz i zdecydowanie to niejako wspólne i słuszne przecież stanowisko, iż podmiotem (podatnikiem) podatku od nieruchomości jest wyłącznie wspólnik stosunku zobowiązaniowego, jakim jest umowa spółki cywilnej. Sama spółka to wyłącznie obligatio i trudno w owym obligatio doszukać się elementu konstrukcyjnego, jakim jest podmiot podatku.

\section{Podsumowanie}

Prowadzenie działalności gospodarczej w formie stosunku zobowiązaniowego, jakim jest umowa spółki cywilnej, zyskało w naszym kraju na popularności. Wpływ na to mają niewątpliwie szybka procedura jej założenia, stosunkowo niewielkie koszty „rejestracji” i mało sformalizowany sposób zawarcia umowy spółki.

Istotne jest również założenie konkretnego celu gospodarczego, jaki zamierzają osiągnąć w ramach jej prowadzenia wspólnicy spółki, oraz zgoda na to, że wszyscy ponoszą równą odpowiedzialność i ryzyko za decyzje biznesowe. Jest to również odpowiedzialność w obszarze świadczeń publicznych, do których ponoszenia w trakcie prowadzenia działalności gospodarczej, w ramach spółki cywilnej zobowiązani są wszyscy jej wspólnicy.

W przedmiotowym opracowaniu podjęto próbę zobrazowania statusu prawnego wspólników spółki cywilnej, jak i samej spółki, jako umowy zobowiązującej do osiągnięcia określonego celu gospodarczego, w oparciu o obowiązek podatkowy w podatku od nieruchomości.

Z przeprowadzonej analizy różnych stanowisk co do podmiotowości podatkowej wspólników spółki i samej spółki wynika, iż przez szereg lat funkcjonowania takiej formy aktywności gospodarczej nie było (poza przedstawicielami doktryny) jednego i zgodnego poglądu na to, kto 
w obszarze tego podatku jest jego podatnikiem, spółka czy jednak jej wspólnicy. Mieliśmy tym samym do czynienia z kolejnym obszarem tzw. niepewności podatkowej, co w konsekwencji skutkowało poważną krytyką poszczególnych uregulowań u.p.o.l.

Dlatego z satysfakcją przyjąć należy, iż aktualnie jest już wypracowane zarówno przez doktrynę, Ministra Finansów, jak i przez sądownictwo administracyjne właściwe rozumienie podmiotowości podatkowej wspólników spółki cywilnej w zakresie ich obowiązków podatkowych. Jednocześnie sytuuje ono umowę spółki cywilnej poza zakresem obowiązku podatkowego w podatku od nieruchomości, w przeciwieństwie do jej wspólników, co w pełni wkomponowuje się w ratio legis omawianych regulacji prawa podatkowego.

\section{Bibliografia:}

Brzezicki T., Lasiński-Sulecki K., Łunarski O., Majka P., Morawski W., J. Wantoch-Rekowski, Podatek od nieruchomości w orzecznictwie sqqdów administracyjnych. Komentarz. Linie interpretacyjne, Wolters Kluwer, Warszawa 2013.

Brzezicki T., Lasiński-Sulecki K., Morawski W., Wantoch-Rekowski J., Ustawa o podatkach i opłatach lokalnych. Komentarz, Ośrodek Doradztwa i Doskonalenia Kadr, Gdańsk 2009.

Brzezicki T., Lasiński-Sulecki K., Morawski W., Majka P., Ustawa o podatkach i opłatach lokalnych. Komentarz, Ośrodek Doradztwa i Doskonalenia Kadr, Gdańsk 2016.

Dudar G., Glosa do wyroku WSA w Krakowie z 3 marca 2009 r., sygn. akt: I SA/Kr 1601/08, „Finanse Komunalne” 2010, nr 4, s. 69-76.

Dudar G., Spółka cywilna w podatku od nieruchomości, „Przegląd Podatków Lokalnych i Finansów Samorządowych”, 2008, nr 7-8, s. 15-23.

Dudar G., Wspólnicy spółki cywilnej jako podatnicy podatku od nieruchomości, „Przegląd Podatków Lokalnych i Finansów Samorządowych” 2015, nr 4, s. 29-36.

Etel L., Presnarowicz S., Dudar G., Podatki i opłaty lokalne, podatek rolny, podatek leśny, Komentarz, Wydawnictwo ABC, Warszawa 2008.

Etel L., Ustawa o podatkach i opłatach lokalnych. Komentarz, Wydawnictwo C.H. Beck, Warszawa 2009. 
Heliniak K., Majka P., Glosa do wyroku Naczelnego Sqqu Administracyjnego z dnia 31 marca 2005 r. (FSK 567/04), „Przegląd Orzecznictwa Podatkowego” 2007, nr 3, s. 212-217.

Kalinowski M., Podmiotowość prawna podatnika, Toruń 1999.

Lic J., Skutki braku podmiotowości spółki cywilnej prowadzq̨cej działalność gospodarczq, „Przegląd Prawa Handlowego”, 2006, nr 1, s. 47-54.

Macudziński M., Czy hale namiotowe podlegajq podatkowi od nieruchomości?, „Prawo Budżetowe Państwa i Samorządu” 2016, nr 4, s. 9-20, DOI: http://dx.doi.org/10.12775/PBPS.2016.020.

Przepisy o podatkach lokalnych, „Dziennik Gazeta Prawna” z dnia 08.05.2017 r., s. B4 (1/2).

Radwański Z., Panowicz-Lipska J., Zobowiq̨zania - część szczegółowa, Wydawnictwo C.H. Beck, Warszawa 2015.

Rymas K. Spółka cywilna podatnikiem podatku od nieruchomości, „Gazeta Podatkowa” 2013, nr 79 (1016), s. 18. 